\title{
Technological optimisation of Picante cheese using microbiological, chemical and physical criteria
}

\author{
A. Cristina Freitas, F. Xavier Malcata * \\ Escola Superior de Biotecnologia, Universidade Católica Portuguesa, Rua Dr. António Bernardino de Almeida, P-4200-072 Porto, Portugal
}

\begin{abstract}
In order to optimise the final quality of Picante cheese, several processing parameters (i.e., volumetric fraction of caprine milk, ripening time and percentage of salt added to fresh cheese) were manipulated and gave rise to a number of experimental cheeses produced according to a second-order, composite factorial design. Microbiological, physicochemical, biochemical and textural analyses were carried out in samples from all experimental cheeses. The most important effect in microbiological terms was produced by ripening time, in both linear and quadratic forms; caprine milk fraction and amount of salt added were also found to be significant factors, again in both linear and quadratic forms, especially with respect to total viable mesophilic microorganisms, Enterobacteriaceae and staphylococci. In terms of proteolysis and lipolysis, ripening time was the dominant factor, but caprine milk fraction and $\mathrm{NaCl}$ content were also significant at the 5\% level. A higher content of caprine milk was associated with higher extents of proteolysis and lipolysis, but the reverse held for $\mathrm{NaCl}$ content. It was concluded that $50-80 \%$ (v/v) caprine milk, ripening for 195 days and $15 \%\left(\mathrm{w} / \mathrm{w}_{\mathrm{TS}}\right) \mathrm{NaCl}$ provide safe counts of Enterobacteriaceae and staphylococci, while maximising proteolysis and lipolysis in Picante cheese. (C) 1999 Elsevier Science Ltd. All rights reserved.
\end{abstract}

Keywords: Dairy foods; Ovine and caprine milk; Processing parameters

\section{Introduction}

Recent years have witnessed improvements in traditional cheesemaking practices driven by governmental and EC regulations, as well as volunteer efforts by researchers developed in a consistent fashion towards characterisation and improvement of traditional dairy products. However, most traditional cheeses are still produced under poor hygienic conditions, following a wide array of manufacturing practices that are dependent on the geographical location and the cheesemaker (Malcata, 1996). One such cheese is Picante, which is produced on the farm level only in interior regions of Portugal.

This research effort has attempted to optimise several quality factors in Picante cheese, using as technological parameters (and hence statistical regressors) those processing variables that are more easily manipulated and play an important role in the final cheese characteristics. Previous work (Freitas \& Malcata, 1996, 1998; Freitas, Fresno, Prieto, Malcata \& Carballo, 1997; Freitas, Pintado, Pintado \& Malcata, 1999) had pointed at the

\footnotetext{
${ }^{*}$ Corresponding author. Tel.: +351-2-5580004; fax: +351-2-590351.
}

percentage of caprine milk, the ripening time and the percentage of salt added as variables that fulfilled the aforementioned requirements even though several other parameters, more difficult to control, could have also been considered (e.g. microbial quality, type and amount of starter, type and amount of rennet, moisture content, final $\mathrm{pH}$ and rate of acidification). The selection of these three parameters also took into account several issues that are important in what concerns manufacture of Picante cheese. In fact, the total variable ovine to caprine volumetric cheesemilk fraction that is allowed by its Appéllation d'Origine Protegée (AOP) regulation is a major cause of variability of the final quality parameters, chiefly extents of proteolysis and lipolysis (Freitas \& Malcata, 1996, 1998; Freitas et al., 1997) as they are determinants of textural and organoleptic parameters, respectively, of ripened cheese. The minimum ripening period for Picante cheese, as set by said AOP regulations, is 120 days (Anon, 1988); however, the better Picante cheeses are often ripened for a longer time, which also aids in ensuring higher microbiological safety because the cheese matrix evolves towards a harsher system for those microorganisms that may pose health hazards (Freitas, Sousa \& Malcata, 1995; Freitas, Pais, 
Malcata \& Hogg, 1996). The percent salt in this type of cheese is rather high, ranging between $10 \%$ and $12 \%(\mathrm{w} /$ w) (Freitas \& Malcata, 1996; Freitas et al., 1997) and is variable from batch to batch, thus leading to high and unpredictable variations in terms of microflora quality and quantity, as well as enzyme-mediated biochemical transformations (Freitas et al., 1995; Freitas \& Malcata, 1996, 1998). Bearing in mind all these technological issues combined with associated costs (note that ovine milk is more expensive than caprine milk, and that a longer ripening period causes greater weight losses), experimental information should to advantage be generated encompassing the caprine milk fraction, the ripening time and the salt percent that optimises manufacture of Picante cheese. Since those factors interact with one another and affect the final cheese characteristics in ways that are difficult to predict in a mechanistic manner, empirical modelling was preferred. Hence, response surface methodologies were employed to locate and characterise the critical points of each parameter: microbiological characteristics assessed were total viable mesophilic microorganisms, Enterobacteriaceae, staphylococci, enterococci, total viable lactic acid bacteria and yeasts; physicochemical characteristics assessed were $\mathrm{pH}$, moisture, protein and fat contents; biochemical characteristics assessed were water-soluble nitrogen, non-protein nitrogen, 5\% phosphotungstic acid-soluble nitrogen and fat acidity; and the textural characteristic assessed was hardness. (For safety reasons, no organoleptic assessment was done, so it was not used as objective function.) The present work represents a further step towards characterisation of Picante cheese, in addition to what was previously reported in Freitas and Malcata $(1996,1998)$ and Freitas et al. (1995, 1996, 1997).

\section{Materials and methods}

\subsection{Experimental design and manufacture}

Response surface methods (Box, Hunter \& Hunter, 1978) were used as a basis for empirical modelling of the independent linear and non-linear effects, and interaction effects, in the design of the experimental layout aimed at defining optimum values for the quality factors. A set of 16 independent experiments (each replicated twice) was thus considered, as depicted in Table 1; correspondence between actual variables (see Table 1) and normalised variables is available in Table 2. The manufacture of cheese was based on the traditional protocol for Picante cheese (Freitas et al., 1996), and modifications of the traditional method were performed where appropriate to obtain quantitative data (on statistically sound grounds) pertaining to the technological aspects under study. Cheese $(1000 \pm 200 \mathrm{~g}, 12 \pm 1.0 \mathrm{~cm}$ diameter and $5 \pm 1 \mathrm{~cm}$ high) were manufactured at an intermediate stage of the lactation season, in a single day, using three milk blends, viz. $20-80 \%, 50-50 \%$ and $80-20 \%(\mathrm{v} / \mathrm{v})$, of caprine-ovine raw milks; coagulation

Table 1

Manufacture parameters for the cheeses produced following the second order experimental design

\begin{tabular}{|c|c|c|c|c|c|c|c|c|c|c|c|c|c|c|c|c|}
\hline \multirow{2}{*}{$\frac{\text { Factor }^{\mathrm{a}}}{L(\% \mathrm{v} / \mathrm{v})}$} & \multicolumn{8}{|c|}{ Corner points } & \multicolumn{6}{|c|}{ Axial points } & \multicolumn{2}{|c|}{ Center points } \\
\hline & 20 & 80 & 20 & 80 & 20 & 80 & 20 & 80 & 20 & 80 & 50 & 50 & 50 & 50 & 50 & 50 \\
\hline$t$ (days) & 45 & 45 & 195 & 195 & 45 & 45 & 195 & 195 & 120 & 120 & 45 & 195 & 120 & 120 & 120 & 120 \\
\hline$s\left(\% \mathrm{w} / \mathrm{w}_{\mathrm{TS}}\right)$ & 12 & 12 & 12 & 12 & 18 & 18 & 18 & 18 & 15 & 15 & 15 & 15 & 12 & 18 & 15 & 15 \\
\hline
\end{tabular}

${ }^{\mathrm{a}} L=$ fraction of caprine milk; $t=$ ripening time; $s=$ concentration of salt added.

Table 2

Equivalence of original and coded factors in the experimental second order design

\begin{tabular}{|c|c|c|c|}
\hline \multicolumn{2}{|l|}{ Factor } & \multicolumn{2}{|l|}{ Value } \\
\hline Original & Code & Original & Code \\
\hline \multirow[t]{3}{*}{ Milk composition } & $L_{1}$ & $20-80 \%$ (v/v) caprine-ovine milk & -1 \\
\hline & $L_{2}$ & $50-50 \%(\mathrm{v} / \mathrm{v})$ caprine-ovine milk & 0 \\
\hline & $L_{3}$ & $80-20 \%(\mathrm{v} / \mathrm{v})$ caprine-ovine milk & +1 \\
\hline \multirow[t]{3}{*}{ Ripening time } & $t_{1}$ & 45 days & -1 \\
\hline & $t_{2}$ & 120 days & 0 \\
\hline & $t_{3}$ & 195 days & +1 \\
\hline \multirow[t]{3}{*}{$\% \mathrm{NaCl}$} & $s_{1}$ & $12 \%\left(\mathrm{w} / \mathrm{w}_{\mathrm{TS}}\right)$ & -1 \\
\hline & $s_{2}$ & $15 \%\left(\mathrm{w} / \mathrm{w}_{\mathrm{TS}}\right)$ & 0 \\
\hline & $s_{3}$ & $18 \%\left(\mathrm{w} / \mathrm{w}_{\mathrm{TS}}\right)$ & +1 \\
\hline
\end{tabular}


took place at an average temperature of $29^{\circ} \mathrm{C}$ during an average time of $50 \mathrm{~min}$ and was effected by commercial animal rennet (Fabre, Monza, Italy) added on a volume basis to the milk (the volume of milk, which varied between 50 and 70 1, was set so as to supply enough cheese replicates for each composition). No deliberate addition of a starter culture took place (the $\mathrm{pH}$ at rennet addition, or at whey drainage, was not standardised). The curd was cut after a prefixed time with $1.5 \mathrm{~cm}$ spaced wires and allowed to rest for about $8 \mathrm{~min}$. The curd was then poured into perforated cylindrical molds made of metal, and was slightly pressed by hand. After ca. $4 \mathrm{~h}$, the cheeses were rubbed with dry salt and maintained in the maturation room for 2 days. After this period the cheeses were transported to the artisanal ripening facilities and rubbed once again with dry salt, grouped in small horizontal sets of 2 or 3 cheeses, and left in that way for 2-3 weeks. The fresh cheeses were salted at $4 \%$, $5 \%$ and $6 \%(\mathrm{w} / \mathrm{w})$, which corresponded to ca. $12 \%, 15 \%$ and $18 \%(\mathrm{w} / \mathrm{w})$ of salt in dry basis. Lower levels of salt were not considered as the final cheese organoleptic characteristics would deviate excessively from those of typical Picante cheese as reported by Freitas and Malcata (1996). The cheeses were then brought together in vertical stacks of several cheeses supported by intercalated layers of clean sand and wheat straw, and maintained in that way for a maximum of 195 days; three ripening times, viz. 45, 120 and 195 days, were assessed. During this period, the cheeses were periodically washed with tap or salted water. The ripening process occurred in the absence of any control of temperature or moisture. Shorthand codes will be used hereafter to denote each experimental cheese; the meanings of these codes in terms of experimental conditions are summarised in Table 2. The sampling method followed consisted in homogenising a great fraction of the replicate cheese in question, and taking random aliquots for microbiological, physicochemical and biochemical assays. From each cheese, two slices (with $6 \pm 0.5 \mathrm{~cm}$ of radius, $6 \pm 0.5$ $\mathrm{cm}$ of width and $4.5 \pm 0.5 \mathrm{~cm}$ of height) were also taken for textural analyses.

\subsection{Microbiological analyses}

Aliquots of $10 \mathrm{~g}$ of unsalted, fresh cheese homogenates, as well as of salted, ripened cheese homogenates were thoroughly mixed with $90 \mathrm{ml}$ of sterile $2 \%(\mathrm{w} / \mathrm{v})$ sodium citrate (Merck, Darmstad, Germany) at $45^{\circ} \mathrm{C}$ for $3 \mathrm{~min}$ in a stomacher Lab-Blender 400 (Seward Medical, UK). Sequential decimal dilutions were made with sterile $0.1 \%$ (w/v) peptone water (Sigma Chemicals, St. Louis MO, USA) from milk samples and from cheese homogenates, and plated in duplicate on a range of media: Plate count agar (PCA) for total viable counts; de Man Rogosa Sharpe agar (MRS) for total counts of lactic acid bacteria; KF Agar (KF) for en- terococci; Potato Dextrose Agar (PDA) for yeasts; Baird Parker Medium (BPM), supplemented with egg yolk tellurite (Lab M, USA), for staphylococci; and Violet Red Bile Glucose Agar (VRBGA) for Enterobacteriaceae. All media were from Lab M (Bury, UK), except KF which was from Merck (Frankfurt, Germany). The MRS Agar was supplemented with cicloheximide $(100 \mathrm{mg} / \mathrm{l})$ (Sigma) to prevent growth of yeasts (Holt, Krieg, Sneath, Staley \& Williams, 1989). Sterile $10 \%(\mathrm{v} / \mathrm{v})$ lactic acid $(10 \mathrm{ml} / \mathrm{l})$ (Merck) was added to PDA to improve selectivity.

\subsection{Physicochemical analyses}

Unless otherwise indicated, the analyses were done according to Richardson (1985) and Kosikowski (1982). The moisture content was determined by the oven method $\left(100^{\circ} \mathrm{C}\right) ; \mathrm{pH}$ values were measured with an electrode for solids (Ingold, Urdorf, Switzerland) connected to a potentiometer Microph 2001 (Crison, Barcelona, Spain); the outer $\mathrm{pH}$ was measured in three top portions of each one of two radial slices per cheese, whereas the inner $\mathrm{pH}$ was measured in three inner portions of each one of three radial slices per cheese. The $\mathrm{NaCl}$ content was determined by the modified Volhard method using silver nitrate and potassium thiocyanate (Merck). The fat content was determined according to the method of van Gulik (Anon, 1975), whereas the protein content was determined by the micro-Kjeldahl method using a Kjeltec System 1002 distilling unit (Tecator, Höganäs, Sweden).

\subsection{Biochemical analyses}

Total nitrogen (TN), water soluble nitrogen (WSN), non-protein nitrogen (NPN) and 5\% phosphotungstic acid-soluble nitrogen ( $5 \%$ PTA-N) were determined by the micro-Kjeldahl method, following a protocol described in detail by Freitas et al. (1997). Acidity index of fat was determined by ethanolic titration following Freitas and Malcata (1998).

\subsection{Textural analyses}

Puncture tests were performed in all cheese samples using a $5 \mathrm{~mm}$ plunger at a constant penetration rate of $20 \mathrm{~mm} / \mathrm{min}$ for a fixed height $(20 \mathrm{~mm})$ in an Instron Puncture Tester 4501 (High Wycombe, Bucks, UK) operated at $23^{\circ} \mathrm{C}$, after having allowed samples to equilibrate at that temperature for $12 \mathrm{~h}$. Puncture tests have been applied to cheese (Chen, Larkin, Clark \& Irwin, 1979) because they are simple to perform and reproducible, although they neglect the viscoelastic nature of the product. The parameter analysed was the value at maximum load, which can be correlated with cheese hardness. 


\subsection{Statistical analyses}

Data obtained from measurements of microbiological, physicochemical, biochemical and textural analyses of cheese were tentatively fitted by minimum leastsquares to a second-degree polynomial model (Box et al., 1978) of the form

$$
\begin{aligned}
\hat{y}= & \bar{y}+\alpha_{1} x_{1}+\alpha_{2} x_{2}+\alpha_{3} x_{3}+\alpha_{12} x_{1} x_{2}+\alpha_{13} x_{1} x_{3} \\
& +\alpha_{23} x_{2} x_{3}+\alpha_{11} x_{1}^{2}+\alpha_{22} x_{2}^{2}+\alpha_{33} x_{3}^{2},
\end{aligned}
$$

where $\hat{y}$ denotes the estimated value of the quality parameter $y, \bar{y}$ is the average of all experimental data for that quality parameter, the $\alpha$ 's are adjustable parameters and the $x$ 's are the technological variables manipulated expressed in normalised form (i.e., $x_{1}$ : effect of milk type, calculated as $(L-50) / 30$, where $L$ is the volumetric percentage of caprine milk in the blend; $x_{2}$ : effect of ripening time, calculated as $(t-120) / 75$, where $t$ is ripening period in days; and $x_{3}$ : effect of salting, calculated as $(s-15) / 3$, where $s$ is the content of $\mathrm{NaCl}$ in $\%(w / w))$.

Diagnostics of residuals for the quadratic model (not shown) were performed in order to check the validity of the regression analyses; since no biased trends were detected, the model was assumed to be valid and used as a basis for reasoning hereafter.

The coordinates of the local optima in terms of the processing variables were determined by differentiating Eq. (1) independently with respect to $x_{1}, x_{2}$ and $x_{3}$, and setting the result thus obtained equal to zero, according to

$$
\left(\frac{\partial \hat{y}}{\partial x_{1}}\right)_{x_{2}, x_{3}}=\left(\frac{\partial \hat{y}}{\partial x_{2}}\right)_{x_{1}, x_{3}}=\left(\frac{\partial \hat{y}}{\partial x_{3}}\right)_{x_{1}, x_{2}}=0 .
$$

The quadratic model denoted by Eq. (1) was further utilised to find analytical values of the optima (and type of optima, as determined from the sign of the corresponding second derivative) for the quality factors considered.
Student's $t$-tests were performed on experimental data obtained from both types of milk.

\section{Results and discussion}

\subsection{Microbiological results}

Microbiological viable counts of the raw ovine and caprine milks used in the manufacture of experimental Picante cheese, as well as of fresh cheese are tabulated in Table 3.

Microbiological viable counts in raw ovine milk were in general higher than those in caprine milk. This realisation agrees with tendencies reported by Freitas et al. (1995), and is evidence of poor sanitary handling conditions that prevail during cheesemaking, especially during milk collection by the farmer and milk handling from the farm to the cheese manufacturer. Student's $t$ tests performed on the microbiological data obtained for each type of milk indicated that, for all microbiological groups, there were statistically significant differences between the two types of milk, except with respect to staphylococci and yeasts.

Microbiological viable counts obtained from each cheese produced according to the second-order experimental design are depicted in Table 4. The estimates for the parameters in Eq. (1) obtained from fits to the microbiological data are also listed in this table. The dominant microorganisms were lactic acid bacteria, mainly enterococci. This agrees with results reported by Freitas et al. (1995) and Freitas and Malcata (1996). Regarding the effects of manufacturing variables studied on microbiological growth, the most important in magnitude was ripening time $\left(x_{2}\right)$, in both linear and quadratic forms (see Table 4). Milk composition $\left(x_{1}\right)$ and amount of salt added $\left(x_{3}\right)$ also appeared as significant factors in both linear and quadratic forms, especially in terms of total viable mesophilic microor-

\begin{tabular}{|c|c|c|c|c|c|}
\hline \multirow[t]{2}{*}{ Microbiological groups } & \multirow[t]{2}{*}{$\begin{array}{l}\text { Ovine milk } \\
\text { (c.f.u. } / \mathrm{ml}_{\text {milk }} \text { ) }\end{array}$} & \multirow[t]{2}{*}{$\begin{array}{l}\text { Caprine milk } \\
\text { (c.f.u. } / \mathrm{ml}_{\text {milk }} \text { ) }\end{array}$} & \multicolumn{3}{|c|}{$\begin{array}{l}\text { Unsalted fresh cheese } \\
\left.\text { (c.f.u. } / g_{\text {cheese }}\right)\end{array}$} \\
\hline & & & $L_{1}$ & $L_{2}$ & $L_{3}$ \\
\hline $\mathrm{TVM}^{\mathrm{b}}$ & $1.21 \times 10^{8}$ & $1.37 \times 10^{6}$ & $4.00 \times 10^{8}$ & $4.25 \times 10^{8}$ & $3.53 \times 10^{8}$ \\
\hline Enterobacteriaceae & $1.67 \times 10^{8}$ & $8.69 \times 10^{4}$ & $1.25 \times 10^{8}$ & $6.40 \times 10^{8}$ & $5.39 \times 10^{8}$ \\
\hline Staphylococci & $3.95 \times 10^{3}$ & $5.33 \times 10^{3}$ & $1.88 \times 10^{4}$ & $4.58 \times 10^{4}$ & $8.00 \times 10^{4}$ \\
\hline $\mathrm{LAB}^{\mathrm{c}}$ & $1.93 \times 10^{7}$ & $2.07 \times 10^{4}$ & $8.75 \times 10^{6}$ & $5.50 \times 10^{7}$ & $7.50 \times 10^{7}$ \\
\hline Enterococci & $3.44 \times 10^{5}$ & $4.42 \times 10^{5}$ & $1.80 \times 10^{6}$ & $2.28 \times 10^{6}$ & $4.22 \times 10^{6}$ \\
\hline Yeasts & $5.38 \times 10^{3}$ & $6.25 \times 10^{3}$ & $1.73 \times 10^{4}$ & $1.05 \times 10^{4}$ & $5.25 \times 10^{4}$ \\
\hline
\end{tabular}

Table 3

Viable numbers obtained in both types of raw cheesemilk and in the three different fresh cheeses (figures are means of sets of duplicated data)

${ }^{\mathrm{a}}$ Colony forming units.

${ }^{\mathrm{b}}$ Total viable microorganisms.

${ }^{\mathrm{c}}$ Lactic acid bacteria.

${ }^{\mathrm{d}} L_{1}-20-80 \%$ caprine-ovine milk; $L_{2}-50-50 \%$ caprine-ovine milk; $L_{3}-80-20 \%$ caprine-ovine milk. Fresh cheese has been manufactured for ca. $4 \mathrm{~h}$. 
Table 4

Microbiological viable numbers of the cheeses manufactured according to the second order experimental design, and estimates of the parameters in Eq. (1) and associated $95 \%$ confidence intervals (effects significant at the $5 \%$ level are denoted in bold)

\begin{tabular}{|c|c|c|c|c|c|c|}
\hline Run-sample & $\begin{array}{l}\text { TVM } \\
\text { (c.f.u./g } / g_{\text {cheese }} \text { ) }\end{array}$ & $\begin{array}{l}\text { Enterobacteriaceae } \\
\text { (c.f.u./g } / g_{\text {cheese }} \text { ) }\end{array}$ & $\begin{array}{l}\text { Staphylococci } \\
\text { (c.f.u./g } / g_{\text {cheese }} \text { ) }\end{array}$ & $\begin{array}{l}\text { Enterococci } \\
\left.\text { (c.f.u. } / g_{\text {cheese }}\right)\end{array}$ & $\begin{array}{l}\text { LAB } \\
\text { (c.f.u. } / g_{\text {cheese }} \text { ) }\end{array}$ & $\begin{array}{l}\text { yeasts } \\
\text { (c.f.u./g } / g_{\text {cheese }} \text { ) }\end{array}$ \\
\hline $1-L_{1} t_{1} s_{1}$ & $1.21 \times 10^{9}$ & $5.75 \times 10^{2}$ & $8.75 \times 10^{6}$ & $1.55 \times 10^{7}$ & $5.28 \times 10^{8}$ & $9.13 \times 10^{6}$ \\
\hline $2-L_{1} t_{1} s_{3}$ & $9.38 \times 10^{8}$ & ND & $1.13 \times 10^{7}$ & $1.08 \times 10^{7}$ & $5.88 \times 10^{8}$ & $1.30 \times 10^{7}$ \\
\hline $3-L_{2} t_{1} s_{2}$ & $7.38 \times 10^{8}$ & $4.28 \times 10^{3}$ & $5.75 \times 10^{6}$ & $1.10 \times 10^{7}$ & $9.00 \times 10^{7}$ & $5.25 \times 10^{6}$ \\
\hline $4-L_{3} t_{1} s_{1}$ & $9.13 \times 10^{8}$ & $1.58 \times 10^{4}$ & $2.50 \times 10^{7}$ & $3.80 \times 10^{7}$ & $5.88 \times 10^{7}$ & $1.15 \times 10^{7}$ \\
\hline $5-L_{3} t_{1} s_{3}$ & $9.00 \times 10^{8}$ & $8.25 \times 10^{2}$ & $2.64 \times 10^{7}$ & $3.93 \times 10^{7}$ & $3.71 \times 10^{8}$ & $9.13 \times 10^{6}$ \\
\hline $6-L_{1} t_{2} s_{2}$ & $1.83 \times 10^{7}$ & $1.20 \times 10^{2}$ & $1.54 \times 10^{5}$ & $4.39 \times 10^{6}$ & $1.11 \times 10^{7}$ & $5.00 \times 10^{3}$ \\
\hline $7-L_{2} t_{2} s_{1}$ & $1.46 \times 10^{7}$ & $2.78 \times 10^{2}$ & $4.38 \times 10^{4}$ & $1.06 \times 10^{6}$ & $2.13 \times 10^{6}$ & $9.63 \times 10^{3}$ \\
\hline $8-L_{2} t_{2} s_{2}$ & $4.88 \times 10^{6}$ & $9.38 \times 10^{2}$ & $1.88 \times 10^{4}$ & $2.91 \times 10^{6}$ & $6.50 \times 10^{6}$ & $1.85 \times 10^{5}$ \\
\hline $9-L_{2} t_{2} s_{2}$ & $8.50 \times 10^{6}$ & $7.05 \times 10^{2}$ & $4.50 \times 10^{4}$ & $2.09 \times 10^{6}$ & $4.38 \times 10^{6}$ & $9.50 \times 10^{4}$ \\
\hline $10-L_{2} t_{2} s_{3}$ & $1.30 \times 10^{7}$ & $6.50 \times 10^{2}$ & $4.00 \times 10^{3}$ & $3.56 \times 10^{6}$ & $1.72 \times 10^{7}$ & $2.38 \times 10^{3}$ \\
\hline $11-L_{3} t_{2} s_{2}$ & $2.56 \times 10^{7}$ & $5.75 \times 10^{1}$ & $2.30 \times 10^{4}$ & $8.50 \times 10^{5}$ & $8.38 \times 10^{6}$ & $1.25 \times 10^{3}$ \\
\hline $12-L_{1} t_{3} s_{1}$ & $1.94 \times 10^{6}$ & ND & $6.00 \times 10^{5}$ & $3.05 \times 10^{4}$ & $4.25 \times 10^{4}$ & ND \\
\hline $13-L_{1} t_{3} s_{3}$ & $2.49 \times 10^{6}$ & ND & $5.75 \times 10^{3}$ & $1.58 \times 10^{4}$ & $7.50 \times 10^{2}$ & ND \\
\hline $14-L_{2} t_{3} s_{2}$ & $3.13 \times 10^{5}$ & ND & ND & $6.50 \times 10^{2}$ & $5.50 \times 10^{2}$ & ND \\
\hline $15-L_{3} t_{3} s_{1}$ & $1.64 \times 10^{6}$ & ND & $4.05 \times 10^{3}$ & $1.98 \times 10^{4}$ & $5.08 \times 10^{3}$ & ND \\
\hline $16-L_{3} t_{3} s_{3}$ & $1.38 \times 10^{6}$ & ND & ND & $1.43 \times 10^{4}$ & $5.75 \times 10^{3}$ & ND \\
\hline \multicolumn{7}{|l|}{ Parameters ${ }^{\mathrm{a}}$} \\
\hline \multirow[t]{2}{*}{$\bar{y}$} & $-2.26 \times 10^{7}$ & $5.17 \times 10^{2}$ & $-1.65 \times 10^{6}$ & $\mathbf{6 . 0 8}^{\mathrm{b}}$ & $6.56^{b}$ & $4.19^{b}$ \\
\hline & $\pm 1.36 \times 10^{6}$ & $\pm 8.71 \times 10^{1}$ & $\pm 9.84 \times 10^{3}$ & \pm 0.06 & \pm 0.08 & \pm 0.11 \\
\hline \multirow[t]{2}{*}{$\alpha_{1}$} & $-3.32 \times 10^{7}$ & $1.59 \times 10^{3}$ & $3.06 \times 10^{6}$ & 0.01 & -0.13 & -0.07 \\
\hline & $\pm \mathbf{1 . 8 1} \times \mathbf{1 0}^{6}$ & $\pm 1.16 \times 10^{2}$ & $\pm 1.31 \times 10^{4}$ & \pm 0.08 & \pm 0.11 & \pm 0.14 \\
\hline \multirow[t]{2}{*}{$\alpha_{2}$} & $-4.69 \times 10^{8}$ & $-2.14 \times 10^{3}$ & $-7.65 \times 10^{6}$ & -1.68 & -2.41 & -7.48 \\
\hline & $\pm \mathbf{1 . 8 1} \times \mathbf{1 0}^{6}$ & $\pm 1.16 \times 10^{2}$ & $\pm 1.31 \times 10^{4}$ & \pm 0.08 & \pm 0.11 & \pm 0.14 \\
\hline \multirow[t]{2}{*}{$\alpha_{3}$} & $-2.89 \times 10^{7}$ & $-1.51 \times 10^{3}$ & $3.24 \times 10^{5}$ & -0.02 & -0.02 & -0.06 \\
\hline & $\pm \mathbf{1 . 8 1} \times \mathbf{1 0}^{6}$ & $\pm 1.16 \times 10^{2}$ & $\pm 1.31 \times 10^{4}$ & \pm 0.08 & \pm 0.11 & \pm 0.14 \\
\hline \multirow[t]{2}{*}{$\alpha_{11}$} & $5.83 \times 10^{7}$ & $-2.81 \times 10^{2}$ & $\mathbf{2 . 5 6} \times 10^{6}$ & 0.32 & 0.48 & -0.35 \\
\hline & $\pm \mathbf{1 . 8 1} \times 10^{6}$ & $\pm 1.16 \times 10^{2}$ & $\pm 1.31 \times 10^{4}$ & \pm 0.08 & \pm 0.11 & \pm 0.14 \\
\hline \multirow[t]{2}{*}{$\alpha_{22}$} & $4.05 \times 10^{8}$ & $1.77 \times 10^{3}$ & $5.35 \times 10^{6}$ & -1.03 & -1.17 & -4.37 \\
\hline & $\pm \mathbf{1 . 8 1} \times 10^{6}$ & $\pm 1.16 \times 10^{2}$ & $\pm 1.31 \times 10^{4}$ & \pm 0.08 & \pm 0.11 & \pm 0.14 \\
\hline \multirow[t]{2}{*}{$\alpha_{33}$} & $5.17 \times 10^{7}$ & $1.01 \times 10^{2}$ & $2.52 \times 10^{6}$ & 0.36 & 0.19 & -0.07 \\
\hline & $\pm \mathbf{1 . 8 1} \times \mathbf{1 0}^{6}$ & $\pm 1.16 \times 10^{2}$ & $\pm 1.31 \times 10^{4}$ & \pm 0.08 & \pm 0.11 & \pm 0.14 \\
\hline \multirow[t]{2}{*}{$\alpha_{12}$} & $4.20 \times 10^{7}$ & $2.00 \times 10^{3}$ & $-4.00 \times 10^{6}$ & -0.15 & 0.11 & 0.01 \\
\hline & $\pm \mathbf{2 . 0 9} \times 10^{6}$ & $\pm 1.34 \times 10^{2}$ & $\pm 1.51 \times 10^{4}$ & \pm 0.09 & \pm 0.12 & \pm 0.16 \\
\hline \multirow[t]{2}{*}{$\alpha_{13}$} & $3.27 \times 10^{7}$ & $-1.79 \times 10^{3}$ & $-6.68 \times 10^{4}$ & 0.04 & 0.32 & -0.03 \\
\hline & $\pm \mathbf{2 . 0 9} \times \mathbf{b}^{6}$ & $\pm 1.34 \times 10^{2}$ & $\pm 1.51 \times 10^{4}$ & \pm 0.09 & \pm 0.12 & \pm 0.16 \\
\hline \multirow[t]{2}{*}{$\alpha_{23}$} & $3.60 \times 10^{7}$ & $1.94 \times 10^{3}$ & $-5.59 \times 10^{5}$ & -0.06 & -0.32 & -0.01 \\
\hline & $\pm \mathbf{2 . 0 9} \times 10^{6}$ & $\pm 1.34 \times 10^{2}$ & $\pm 1.51 \times 10^{4}$ & \pm 0.09 & \pm 0.12 & \pm 0.16 \\
\hline
\end{tabular}

a 1 - effect of milk type; 2 - effect of ripening time; 3 - effect of salt addition.

${ }^{\mathrm{b}}$ Owing to non-normal behaviour of the experimental residues, logarithms of the data rather the data themselves were used.

ND - Not detected.

$L_{1}-20-80 \%$ caprine-ovine milk; $L_{2}-50-50 \%$ caprine-ovine milk; $L_{3}-80-20 \%$ caprine-ovine milk; $t_{1}-45$ days; $t_{2}-120$ days; $t_{3}-195$ days; $s_{1}-$ $12 \%\left(\mathrm{w} / \mathrm{w}_{\mathrm{TS}}\right) ; s_{2}-15 \%\left(\mathrm{w} / \mathrm{w}_{\mathrm{TS}}\right) ; s_{3}-18 \%\left(\mathrm{w} / \mathrm{w}_{\mathrm{TS}}\right)$.

ganisms, Enterobacteriaceae and staphylococci. In general, $\mathrm{NaCl}$ content and, to a lesser extent, volumetric fraction of caprine milk in the milk blend played negative roles, i.e., higher values of these factors led to lower microbiological viable counts. The effect of milk type may likely be ascribed to the different adventitious microflora of the milks from distinct animal sources (see Table 3). The effect of salt content on these microbiological groups was not surprising owing to the role of $\mathrm{NaCl}$ in increasing osmotic pressure and in lowering $a_{\mathrm{w}}$, both of which have frequently been employed to control microbial growth (Marshall, Ohye \& Christian, 1971; Measure, 1975).
In terms of enterococci, total lactic acid bacteria (LAB) and yeasts, only the ripening time was clearly significant; in addition, milk composition was also significant for LAB (note that the experimental data for enterococci, total lactic acid bacteria and yeasts had to be logarithmily transformed owing to non-independence of residuals and non-constancy of variance). Those results contrast with data reported by Freitas and Malcata (1996); however, Freitas and Malcata (1998) claimed that some of the main species of lactobacilli, enterococci and yeasts found in Picante cheese (viz. Lactobacillus plantarum and L. paracasei, Enterococcus faecium and E. faecalis, and Debaryomyces hansenii) can resist up to 
$14 \%(\mathrm{w} / \mathrm{v}) \mathrm{NaCl}$. All quadratic effects (with exception of $x_{3}$ for yeasts) were found to be statistically significant.

\subsection{Physicochemical results}

Experimental data pertaining to the physicochemical properties of the two types of raw milk and fresh experimental cheese are tabulated in Table 5.

The acidity of ovine milk is higher than that of caprine milk. Although this fact could be an indicator of microbiological contamination (higher viable counts were in fact recorded in ovine than in caprine milk, see Table 3), the relatively similar $\mathrm{pH}$ values for the two types of milk unfolds the influence of the higher protein content in ovine milk (which, upon proteolysis, may generate further free acidic groups). According to Student's $t$-tests, all physicochemical parameters, except density and $\mathrm{pH}$, were significantly different between the two types of milk. As expected, the decreasing values of total protein and fat from $L_{1}(20-80 \%(\mathrm{v} / \mathrm{v})$ of ovine and caprine milks, respectively) to $L_{3}(80-20 \%(\mathrm{v} / \mathrm{v})$ of ovine and caprine milks, respectively) in fresh form are directly correlated with protein and fat contents of each milk type (see Table 5).

The physicochemical data obtained from each cheese, as well as estimates for the parameters in Eq. (1), are tabulated in Table 6.

The $\mathrm{pH}$ of the inner and outer regions of the experimental cheeses increased throughout ripening as a consequence of consumption of lactic acid via biochemical pathways by the microflora; as expected in view of the preferential anaerobic production of lactic acid, the outer $\mathrm{pH}$ values were in general higher than their inner counterparts. The effect accounted for by the added salt on both $\mathrm{pH}$ values probably arises through its negative effect in terms of critical microbiological groups (see Table 4). Since the cheeses used in this study were of similar dimensions, it is expected that salt-in-moisture equilibrium would be achieved in virtually similar times (Geurts, Walstra \& Mulder, 1974a,b, 1980); hence, it is unexpected that differences in salt concentration will be responsible for differences in $\mathrm{pH}$ between the outer and inner regions at 45, 120 and 195 days. Conversely, if one remembers that the high contents of $\mathrm{NaCl}$, especially in the first days of ripening, drive qualitative and quantitative selection of the microflora, those $\mathrm{pH}$ differences might easily be accounted for.

Increasing the fraction of caprine milk in the cheesemilk blend led to a significant effect, and produced higher moisture content and lower protein and fat contents; these parameters can be directly related to the different solid contents of each type of milk (see Table 5). These data per se emphasise the strong implications on cheese final characteristics that arise from manufacture of Picante cheese with variable volumetric fractions of caprine and ovine milks. Ripening time was also an important effect, mainly in terms of moisture content. Note that longer ripening periods produce higher losses in terms of cheese weight, with consequent negative impact upon revenues. The amount of salt added was also a significant factor for the protein and fat contents, and especially for the moisture content (see Table 6). In terms of fat and protein, the negative effect caused by higher contents of (added) salt is probably related with the fact that expression of residual whey in fresh cheeses is a function of the quantity of $\mathrm{NaCl}$ rubbed on their surface. As already described by Freitas and Malcata (1996), Picante cheeses with higher $\mathrm{NaCl}$ content exhibit higher moisture content. This result, which at a first glance appears to be contradictory (since it is expected that higher $\mathrm{NaCl}$ levels should have a stronger desiccating effect) may actually derive from the fact that higher $\mathrm{NaCl}$ levels may imply more molecular water bound to salt; this is observed owing to its hygroscopic nature, even though $a_{\mathrm{w}}$ will more likely approach its typical saturation value of 0.75 . Since $\mathrm{NaCl}$ played a positive role in terms of moisture, as expected, it consequently played a negative effect upon solids content, which is intimately associated with protein and fat contents.

Table 5

Physicochemical data obtained in both types of raw cheesemilk and in the three different fresh cheeses (figures are means of sets of duplicated data)

\begin{tabular}{|c|c|c|c|c|c|}
\hline \multirow[t]{2}{*}{ Physicochemical properties } & \multirow[t]{2}{*}{ Ovine milk } & \multirow[t]{2}{*}{ Caprine milk } & \multicolumn{3}{|c|}{ Unsalted fresh cheese $^{\mathrm{a}}$} \\
\hline & & & $L_{1}$ & $L_{2}$ & $L_{3}$ \\
\hline Density $\left(\mathrm{g} / \mathrm{cm}^{3}\right)$ & 1.03 & 1.03 & - & - & - \\
\hline Acidity $\left({ }^{\circ} \mathrm{D}\right)$ & 26.0 & 20.3 & - & - & - \\
\hline Moisture $(\% \mathrm{w} / \mathrm{w})$ & - & - & 65.47 & 68.59 & 68.76 \\
\hline Total fat $(\% \mathrm{w} / \mathrm{w})$ & 6.53 & 4.37 & 18.25 & 16.25 & 14.88 \\
\hline Casein $(\% \mathrm{w} / \mathrm{w})$ & 4.25 & 2.98 & - & - & - \\
\hline Total protein $(\% \mathrm{w} / \mathrm{w})$ & - & - & 14.20 & 13.01 & 12.53 \\
\hline $\mathrm{pH}$ & 6.67 & 6.69 & 6.46 & 6.47 & 6.59 \\
\hline
\end{tabular}

${ }^{\mathrm{a}} L_{1}-20-80 \%$ caprine-ovine milk; $L_{2}-50-50 \%$ caprine-ovine milk; $L_{3}-80-20 \%$ caprine-ovine milk. Fresh cheese has been manufactured for ca. 4 h. 
Table 6

Physicochemical data of the cheeses manufactured according to the second order experimental design, and estimates of the parameters in Eq. (1) and associated $95 \%$ confidence intervals (effects significant at the $5 \%$ level are denoted in bold)

\begin{tabular}{|c|c|c|c|c|c|}
\hline Run-sample & Outer $\mathrm{pH}$ & Inner $\mathrm{pH}$ & Moisture $(\% \mathrm{w} / \mathrm{w})$ & Protein $(\% \mathrm{w} / \mathrm{w})$ & Fat $(\% \mathrm{w} / \mathrm{w})$ \\
\hline $1-L_{1} t_{1} s_{1}$ & 5.29 & 4.75 & 41.72 & 21.65 & 34.50 \\
\hline $2-L_{1} t_{1} s_{3}$ & 5.36 & 4.80 & 46.16 & 18.73 & 29.25 \\
\hline $4-L_{3} t_{1} s_{1}$ & 5.20 & 4.86 & 47.12 & 17.46 & 27.75 \\
\hline $5-L_{3} t_{1} s_{3}$ & 5.32 & 4.95 & 49.58 & 16.44 & 26.13 \\
\hline $6-L_{1} t_{2} S_{2}$ & 5.84 & 5.52 & 39.59 & 21.77 & 35.25 \\
\hline $9-L_{2} t_{2} s_{2}$ & 5.71 & 5.57 & 42.28 & 18.88 & 31.25 \\
\hline $10-L_{2} t_{2} s_{3}$ & 5.67 & 5.55 & 49.50 & 16.41 & 27.00 \\
\hline $11-L_{3} t_{2} S_{2}$ & 5.98 & 5.78 & 43.51 & 18.40 & 29.63 \\
\hline $12-L_{1} t_{3} s_{1}$ & 5.76 & 5.73 & 42.99 & 20.67 & 34.75 \\
\hline $13-L_{1} t_{3} s_{3}$ & 5.45 & 5.49 & 41.60 & 20.33 & 31.75 \\
\hline $14-L_{2} t_{3} s_{2}$ & 5.42 & 5.40 & 45.12 & 18.10 & 28.75 \\
\hline \multicolumn{6}{|l|}{ Parameters $^{\mathrm{a}}$} \\
\hline$\alpha_{1}$ & $-0.01 \pm 0.02$ & $0.03 \pm 0.02$ & $1.41 \pm 0.34$ & $-1.32 \pm 0.29$ & $-2.25 \pm 0.25$ \\
\hline$\alpha_{2}$ & $0.11 \pm 0.02$ & $0.34 \pm 0.02$ & $-0.83 \pm 0.34$ & $0.26 \pm 0.29$ & $0.54 \pm 0.25$ \\
\hline$\alpha_{3}$ & $-0.05 \pm 0.02$ & $-0.03 \pm 0.02$ & $1.92 \pm 0.34$ & $-0.96 \pm 0.29$ & $-1.90 \pm 0.25$ \\
\hline$\alpha_{11}$ & $0.08 \pm 0.02$ & $0.07 \pm 0.02$ & $-0.59 \pm 0.34$ & $0.76 \pm 0.29$ & $0.98 \pm 0.25$ \\
\hline$\alpha_{22}$ & $-0.38 \pm 0.02$ & $-0.45 \pm 0.02$ & $0.13 \pm 0.34$ & $-0.31 \pm 0.29$ & $-1.18 \pm 0.25$ \\
\hline$\alpha_{33}$ & $-0.03 \pm 0.02$ & $0.03 \pm 0.02$ & $2.47 \pm 0.34$ & $-0.57 \pm 0.29$ & $-0.76 \pm 0.25$ \\
\hline$\alpha_{12}$ & $0.01 \pm 0.02$ & $-0.06 \pm 0.02$ & $-0.94 \pm 0.40$ & $\mathbf{0 . 3 7} \pm \mathbf{0 . 3 3}$ & $0.36 \pm 0.29$ \\
\hline$\alpha_{13}$ & $0.03 \pm 0.02$ & $0.02 \pm 0.02$ & $0.36 \pm 0.40$ & $0.16 \pm 0.33$ & $0.58 \pm 0.29$ \\
\hline$\alpha_{23}$ & $-0.08 \pm 0.02$ & $-0.07 \pm 0.02$ & $-0.60 \pm 0.40$ & $0.33 \pm 0.33$ & $0.23 \pm 0.29$ \\
\hline
\end{tabular}

${ }^{\mathrm{a}} 1$ - effect of milk type; 2 - effect of ripening time; 3 - effect of salt addition. $L_{1}-20-80 \%$ caprine-ovine milk; $L_{2}-50-50 \%$ caprine-ovine milk; $L_{3}-$ $80-20 \%$ caprine-ovine milk; $t_{1}-45$ days; $t_{2}-120$ days; $t_{3}-195$ days; $s_{1}-12 \%\left(\mathrm{w} / \mathrm{w}_{\mathrm{TS}}\right) ; s_{2}-15 \%\left(\mathrm{w} / \mathrm{w}_{\mathrm{TS}}\right) ; s_{3}-18 \%\left(\mathrm{w} / \mathrm{w}_{\mathrm{TS}}\right)$.

\subsection{Biochemical results}

Experimental data pertaining to proteolysis (WSN, NPN and 5\% PTA-N fractions) and lipolysis (fat acidity) of the three fresh cheese produced are tabulated in Table 7. Inspection of this table indicates that a higher proportion of caprine milk in the cheesemilk blend leads to more extensive proteolysis, even in fresh cheese. This tendency was confirmed by the data generated on cheese samples that are depicted in Table 8 . This fact agrees,

Table 7

Biochemical data obtained in the three different fresh cheeses (figures are means of sets of duplicated data)

\begin{tabular}{llll}
\hline \multirow{2}{*}{ Biochemical properties } & \multicolumn{3}{l}{ Unsalted fresh cheese ${ }^{\mathrm{a}}$} \\
\cline { 2 - 4 } & $L_{1}$ & $L_{2}$ & $L_{3}$ \\
\hline WSN (\% TN) & 5.93 & 7.70 & 7.79 \\
NPN-N (\% TN) & 2.90 & 3.36 & 3.42 \\
$5 \%$ PTA-N (\% TN) & 2.43 & 2.63 & 3.25 \\
Fat acidity $\left(\mathrm{mg}_{\text {КОН }} / \mathrm{g}_{\text {fat }}\right)$ & 0.297 & 0.291 & 0.332 \\
\hline
\end{tabular}

${ }^{a} L_{1}-20-80 \%$ caprine-ovine milk; $L_{2}-50-50 \%$ caprine-ovine milk; $L_{3}$ $-80-20 \%$ caprine-ovine milk. Fresh cheese has been manufactured for ca. $4 \mathrm{~h}$. and further confirms, results reported by Freitas et al. (1997), but contrasts with data reported by Mallatou, Pappas and Voutsinas (1994). The higher moisture content in cheese with higher contents of caprine milk, as well as the lower amount of protein in caprine milk, probably promote proteolysis; the rate of proteolysis is actually known to be influenced by the ratio of casein to moisture (Lawrence, Heap \& Gilles, 1984). According to Guinee and Wilkinson (1992), changes in the rennet-tocasein ratio (due to changes in milk composition) is also one process that likely gives rise to variations in residual rennet activity. This ratio increased when going from ovine to caprine milk (because the same amount of animal rennet was added to coagulate all different batches of milk), so this constitutes a possible justification for the aforementioned positive effect of milk composition upon WSN. The structure of milk caseins probably implicates differences in their degradation mechanisms because caprine milk casein micelles have a greater diameter (and wider size dispersion) than ovine casein micelles (Richardson, Creamer \& Pearce, 1974; Bucheim, Lund \& Scholtissek, 1989). The linear effect of milk composition was higher on WSN and NPN than on $5 \%$ PTA-N. Since microbiological viable numbers 
Table 8

Biochemical and textural data of the cheeses manufactured according to the second order experimental design, and estimates of the parameters in Eq. (1) and associated $95 \%$ confidence intervals (effects significant at the $5 \%$ level are denoted in bold)

\begin{tabular}{|c|c|c|c|c|c|}
\hline Run-sample & $\mathrm{WSN}\left(\% \mathrm{w} / \mathrm{W}_{\mathrm{TN}}\right)$ & NPN-N (\% w/w $\left./ \mathrm{w}_{\mathrm{TN}}\right)$ & $5 \%$ PTA-N $\left(\% \mathrm{w} / \mathrm{w}_{\mathrm{TN}}\right)$ & Fat acidity $\left(\mathrm{mg}_{\mathrm{KOH}} / \mathrm{g}_{\mathrm{fat}}\right)$ & Hardness $(\mathrm{N})$ \\
\hline $1-L_{1} t_{1} s_{1}$ & 14.74 & 9.19 & 3.01 & 7.79 & 5.30 \\
\hline $2-L_{1} t_{1} s_{3}$ & 12.67 & 6.47 & 2.55 & 7.09 & 4.23 \\
\hline $3-L_{2} t_{1} s_{2}$ & 14.66 & 9.49 & 3.26 & 9.27 & 4.23 \\
\hline $4-L_{3} t_{1} s_{1}$ & 16.47 & 10.62 & 3.56 & 10.27 & 3.35 \\
\hline $5-L_{3} t_{1} s_{3}$ & 13.06 & 8.43 & 2.77 & 6.81 & 2.25 \\
\hline $6-L_{1} t_{2} s_{2}$ & 16.03 & 12.20 & 4.56 & 9.21 & 14.88 \\
\hline $7-L_{2} t_{2} s_{1}$ & 18.33 & 14.73 & 6.95 & 18.94 & 9.65 \\
\hline $8-L_{2} t_{2} s_{2}$ & 18.84 & 13.99 & 6.00 & 14.31 & 7.88 \\
\hline $9-L_{2} t_{2} s_{2}$ & 17.01 & 13.81 & 5.66 & 14.84 & 7.83 \\
\hline $10-L_{2} t_{2} s_{3}$ & 20.52 & 13.10 & 5.24 & 10.89 & 6.60 \\
\hline $11-L_{3} t_{2} s_{2}$ & 22.30 & 15.46 & 5.86 & 16.45 & 7.33 \\
\hline $12-L_{1} t_{3} s_{1}$ & 30.64 & 23.25 & 12.06 & 19.71 & 3.60 \\
\hline $13-L_{1} t_{3} s_{3}$ & 27.04 & 21.42 & 10.37 & 14.93 & 5.95 \\
\hline $14-L_{2} t_{3} s_{2}$ & 34.15 & 27.03 & 12.30 & 28.61 & 4.35 \\
\hline $15-L_{3} t_{3} s_{1}$ & 33.58 & 25.69 & 12.18 & 31.62 & 5.18 \\
\hline $16-L_{3} t_{3} s_{3}$ & 28.12 & 25.65 & 11.44 & 18.71 & 4.53 \\
\hline \multicolumn{6}{|l|}{ Parameters $^{\mathrm{a}}$} \\
\hline $\bar{y}$ & $19.32 \pm 0.69$ & $14.40 \pm 0.07$ & $5.87 \pm 0.13$ & $15.37 \pm 0.20$ & $8.82 \pm 0.02$ \\
\hline$\alpha_{1}$ & $1.24 \pm 0.91$ & $1.33 \pm 0.09$ & $0.33 \pm 0.17$ & $2.52 \pm 0.26$ & $-1.13 \pm 0.03$ \\
\hline$\alpha_{2}$ & $8.19 \pm 0.91$ & $7.89 \pm 0.09$ & $4.32 \pm 0.17$ & $7.24 \pm 0.26$ & $0.43 \pm 0.03$ \\
\hline$\alpha_{3}$ & $-1.24 \pm 0.91$ & $-0.84 \pm 0.09$ & $-0.54 \pm 0.17$ & $-2.99 \pm 0.26$ & $-0.35 \pm 0.03$ \\
\hline$\alpha_{11}$ & $-0.90 \pm 0.91$ & $-0.86 \pm 0.09$ & $-0.71 \pm 0.17$ & $-2.97 \pm 0.26$ & $1.79 \pm 0.03$ \\
\hline$\alpha_{22}$ & $4.36 \pm 0.91$ & $3.58 \pm 0.09$ & $1.87 \pm 0.17$ & $3.16 \pm 0.26$ & $-5.02 \pm 0.03$ \\
\hline$\alpha_{33}$ & $-0.55 \pm 0.91$ & $-0.71 \pm 0.09$ & $0.21 \pm 0.17$ & $-0.82 \pm 0.26$ & $-1.16 \pm 0.03$ \\
\hline$\alpha_{12}$ & $0.24 \pm 1.06$ & $0.41 \pm 0.10$ & $0.05 \pm 0.20$ & $1.67 \pm 0.31$ & $0.51 \pm 0.03$ \\
\hline$\alpha_{13}$ & $-0.40 \pm 1.06$ & $0.29 \pm 0.10$ & $0.08 \pm 0.20$ & $-1.36 \pm 0.31$ & $-0.38 \pm 0.03$ \\
\hline$\alpha_{23}$ & $-0.45 \pm 1.06$ & $0.38 \pm 0.10$ & $-0.15 \pm 0.20$ & $-1.69 \pm 0.31$ & $0.48 \pm 0.03$ \\
\hline
\end{tabular}

a 1 - effect of milk type; 2 - effect of ripening time; 3 - effect of salt addition. $L_{1}-20-80 \%$ caprine-ovine milk; $L_{2}-50-50 \%$ caprine-ovine milk; $L_{3}-$ 80-20\% caprine-ovine milk; $t_{1}-45$ days; $t_{2}-120$ days; $t_{3}-195$ days; $s_{1}-12 \%\left(\mathrm{w} / \mathrm{w}_{\mathrm{TS}}\right) ; s_{2}-15 \%\left(\mathrm{w} / \mathrm{w}_{\mathrm{TS}}\right) ; s_{3}-18 \%\left(\mathrm{w} / \mathrm{w}_{\mathrm{TS}}\right)$.

were higher in cheese manufactured with higher content of ovine milk, this realisation could explain the lower effect of milk composition on 5\% PTA-N. Remember that the initial proteolysis of caseins during ripening is caused chiefly by residual rennet (and/or plasmin), and results in the formation of large- and medium-sized peptides, which are then further degraded by the proteinase/peptidase systems of starter and non-starter bacteria to peptides and free amino acids (Kleter, 1977; Visser, 1977a,b, 1993; Wilkinson, Guinee, O'Callaghan \& Fox, 1992).

The other two manufacturing variables $\left(x_{2}\right.$ and $\left.x_{3}\right)$, in their linear and quadratic forms, were also statistically significant (except with regard to the quadratic effect of amount of salt added upon WSN). Ripening time, as already observed by Freitas and Malcata (1996) and Freitas et al. (1997), was the dominant factor in terms of proteolytic evolution. The important negative effect of $\mathrm{NaCl}$ on proteolysis was expected because, following Guinee and Fox (1993), its major impact on cheese ripening is via its action upon $a_{\mathrm{w}}$, which in turn controls the activity of the various enzymes in cheese. The relatively high levels of soluble nitrogen in cheese with lower $\mathrm{NaCl}$ contents can then be attributed to a considerable activity of the microflora under those favourable envi- ronmental conditions (Schroeder, Bodyfelt, Wyatt \& McDaniel, 1988).

The pattern of significant effects regarding lipolysis was similar to those found for proteolysis. Once more, a high proportion of caprine milk in cheesemilk was associated with higher rates and extents of lipolysis, in agreement with data reported by Mallatou et al. (1994). According to Albrecht and Jaynes (1955), the main source of lipases in cheese is milk itself and its indigenous microflora. As mentioned above, increasing the $\mathrm{NaCl}$ content in cheese contributes to reducing the number of microorganisms; additionally, the ionic strength in cheese (which in turn depends directly on salt content) controls the activity of enzymes by constraining their conformation, and hence their catalytic efficiency (Malcata, 1996). Therefore, the negative sign of the $\mathrm{NaCl}$ effect upon fat acidity was expected (see Table 8).

Since cheese manufactured with a higher fraction of caprine milk and with a lower content of $\mathrm{NaCl}$ became less dry and underwent more extensive proteolysis and lipolysis, lower hardness values were expected for this type of cheese. These presumptions were confirmed by the estimated values for both the linear and the quadratic effects (see Table 8). 


\subsection{Statistical results}

Optima regarding each parameter could have been found from direct application of Eq. (2). However, eight distinct optima were obtained, as typically happens with most optimisation procedures involving a considerable numbers of factors (Nabais \& Malcata, 1995; Pintado, Silva \& Malcata, 1996; Macedo \& Malcata, 1998; Gomes \& Malcata, 1998), which do not coincide with one another. Inspection of Tables 9 and 10 indicates that only three true optima were found (two true minima for TVM and for staphylococci, and a true maximum for yeasts). For the other parameters, a true minimum or maximum could not be found, i.e., their loci were all saddle points (or equivalently, the critical points corresponded to a minimum for some variable(s) and a maximum for the other(s)). Therefore, no clear definition was obtained as to which technological direction should be taken for standardisation of Picante cheesemaking.

Since it was not possible to apply the statistical model to sensorial characteristics owing to the fact that cheese younger than 120 days cannot yet be sold as there is a health risk associated with human consumption (Anon, 1988), the optimisation procedures could not be based on the organoleptic characteristics. However, Picante cheese is known to exhibit a moderate ripening extension index and a high ripening depth index (Freitas et al., 1997); according to Furtado and Partridge (1998), the former is a measure of moderate rennet activity and the later is an indication of a strong starter peptidase activity. This cheese also displays high levels of lipolysis
(Freitas \& Malcata, 1998). Therefore, these parameters will consequently be further considered towards optimisation. For most hard and semi-hard cheese varieties, proteolysis is the most commonly used index of maturation (Farkye \& Fox, 1990) because this set of biochemical phenomena contribute strongly to flavour and texture development (Guinee \& Wilkinson, 1992). According to Woo, Kollodge and Lindsay (1984), lipolysis is also of major importance, especially in long ripened hard cheeses. It was observed that cheese manufactured with a higher caprine milk fraction and a lower $\mathrm{NaCl}$ content did undergo more extensive proteolysis and lipolysis (Freitas \& Malcata, 1996); hence, maximising the extent of both biochemical phenomena would be associated with maximisation of the fractional content of caprine milk in the cheesemilk blend, as well as minimisation of the $\mathrm{NaCl}$ content in cheese. These two facts are of economic interest because caprine milk is less expensive than ovine milk, and of nutritional interest because a lower dietary intake of $\mathrm{NaCl}$ is better for health. Since most public health concerns are laid on microbiological safety issues, minimisation of viability of undesirable microbiological groups would also be of a high interest. Therefore, three biochemical factors (i.e., WSN, NPN-N and fat acidity) and two microbiological factors (i.e., Enterobacteriaceae and staphylococci viable counts) will be considered.

Detailed inspection of Tables 9 and 10 regarding numbers of Enterobacteriaceae, WSN, NPN-N and fat acidity indicates that obtaining a global optimum raises the need to a priori impose few restrictions on the technological variables. For the global minimum of

Table 9

Loci (LO) and type (TO) of optima, in terms of each normalised technological variable, associated with the quadratic models fitted to the experimental data pertaining to microbiological factors (MF)

\begin{tabular}{|c|c|c|c|c|}
\hline Factor type & Parameter & Variable & LO & TO \\
\hline \multirow[t]{3}{*}{ MF } & \multirow[t]{3}{*}{ TVM $^{\mathrm{a}}$ (c.f.u. $/ \mathrm{g}_{\text {cheese }}$ ) } & $x_{1}$ & $0.285-0.361 x_{2}-0.281 x_{3}$ & Min \\
\hline & & $x_{2}$ & $0.579-0.052 x_{1}-0.044 x_{3}$ & Min \\
\hline & & $x_{3}$ & $0.280-0.317 x_{1}-0.348 x_{2}$ & Min \\
\hline \multirow[t]{3}{*}{ MF } & \multirow[t]{3}{*}{ Enterobacteriaceae (c.f.u./g $\mathrm{g}_{\text {cheese }}$ ) } & $x_{1}$ & $2.836-3.599 x_{2}-0.341 x_{3}$ & Max \\
\hline & & $\mathrm{x}_{2}$ & $0.605+0.565 x_{1}-0.547 x_{3}$ & Min \\
\hline & & $x_{3}$ & $7.462+8.841 x_{1}-9.957 x_{2}$ & Min \\
\hline \multirow[t]{3}{*}{ MF } & \multirow[t]{3}{*}{ Staphylococci (c.f.u./g cheese $_{\text {) }}$ ) } & $x_{1}$ & $-0.598+0.780 x_{2}+0.013 x_{3}$ & Min \\
\hline & & $x_{2}$ & $0.715+0.373 x_{1}+0.052 x_{3}$ & Min \\
\hline & & $x_{3}$ & $-0.064+0.013 x_{1}+0.111 x_{2}$ & Min \\
\hline \multirow[t]{3}{*}{ MF } & \multirow[t]{3}{*}{ Enterococci $\log$ (c.f.u. $\left./ \mathrm{g}_{\text {cheese }}\right)$} & $x_{1}$ & $-0.002+0.228 x_{2}-0.062 x_{3}$ & Min \\
\hline & & $x_{2}$ & $-0.817-0.071 x_{1}-0.029 x_{3}$ & $\operatorname{Max}$ \\
\hline & & $x_{3}$ & $0.034-0.055 x_{1}+0.081 x_{2}$ & Max \\
\hline \multirow[t]{3}{*}{ MF } & \multirow[t]{3}{*}{$\mathrm{LAB}^{\mathrm{b}} \log \left(\right.$ c.f.u. $\left./ \mathrm{g}_{\text {cheese }}\right)$} & $x_{1}$ & $0.136-0.119 x_{2}-0.341 x_{3}$ & Min \\
\hline & & $x_{2}$ & $-1.029+0.048 x_{1}-0.135 x_{3}$ & Max \\
\hline & & $x_{3}$ & $0.053-0.852 x_{1}+0.830 x_{2}$ & Min \\
\hline \multirow[t]{3}{*}{ MF } & \multirow[t]{3}{*}{ Yeasts $\log \left(\right.$ c.f.u. $\left./ g_{\text {cheese }}\right)$} & $x_{1}$ & $-0.094+0.011 x_{2}-0.043 x_{3}$ & Max \\
\hline & & $x_{2}$ & $-0.855+0.001 x_{1}-0.001 x_{3}$ & Max \\
\hline & & $x_{3}$ & $-0.401-0.208 x_{1}-0.056 x_{2}$ & Max \\
\hline
\end{tabular}

\footnotetext{
a Total viable microorganisms;

${ }^{\mathrm{b}}$ Lactic acid bacteria.
} 
Table 10

Loci (LO) and type (TO) of optima, in terms of each normalised technological variable, associated with the quadratic models fitted to the experimental data pertaining to physicochemical factors (PCF), biochemical factors (BF) and textural factor (TF)

\begin{tabular}{|c|c|c|c|c|}
\hline Factor type & Parameter & Variable & $\mathrm{LO}$ & TO \\
\hline \multirow[t]{3}{*}{ PCF } & Outer $\mathrm{pH}$ & $x_{1}$ & $0.075+0.003 x_{2}-0.160 x_{3}$ & Min \\
\hline & & $x_{2}$ & $0.142-0.001 x_{1}-0.104 x_{3}$ & Max \\
\hline & & $x_{3}$ & $-0.719+0.418 x_{1}-1.246 x_{2}$ & $\operatorname{Max}$ \\
\hline \multirow[t]{3}{*}{ PCF } & Inner $\mathrm{pH}$ & $x_{1}$ & $-0.224+0.417 x_{2}-0.121 x_{3}$ & Min \\
\hline & & $x_{2}$ & $0.378-0.063 x_{1}-0.073 x_{3}$ & $\operatorname{Max}$ \\
\hline & & $x_{3}$ & $0.542-0.288 x_{1}+1.162 x_{2}$ & Min \\
\hline \multirow[t]{3}{*}{ PCF } & Moisture $(\% \mathrm{w} / \mathrm{w})$ & $x_{1}$ & $1.193-0.797 x_{2}+0.307 x_{3}$ & Max \\
\hline & & $x_{2}$ & $3.158+3.568 x_{1}+2.276 x_{3}$ & Min \\
\hline & & $x_{3}$ & $-0.388-0.073 x_{1}+0.121 x_{2}$ & Min \\
\hline \multirow[t]{3}{*}{ PCF } & Protein $(\% \mathrm{w} / \mathrm{w})$ & $x_{1}$ & $0.868-0.240 x_{2}-0.106 x_{3}$ & Min \\
\hline & & $x_{2}$ & $0.413+0.585 x_{1}+0.529 x_{3}$ & Max \\
\hline & & $x_{3}$ & $-0.837+0.142 x_{1}+0.289 x_{2}$ & $\operatorname{Max}$ \\
\hline \multirow[t]{3}{*}{ PCF } & Fat $(\% \mathrm{w} / \mathrm{w})$ & $x_{1}$ & $1.145-0.183 x_{2}-0.294 x_{3}$ & Min \\
\hline & & $x_{2}$ & $0.229+0.153 x_{1}+0.100 x_{3}$ & $\operatorname{Max}$ \\
\hline & & $x_{3}$ & $-1.250+0.380 x_{1}+0.154 x_{2}$ & $\operatorname{Max}$ \\
\hline \multirow[t]{3}{*}{$\mathrm{BF}$} & $\mathrm{WSN}\left(\% \mathrm{w} / \mathrm{w}_{\mathrm{TN}}\right)$ & $x_{1}$ & $0.690+0.133 x_{2}-0.223 x_{3}$ & Max \\
\hline & & $x_{2}$ & $-0.939-0.027 x_{1}+0.051 x_{3}$ & Min \\
\hline & & $x_{3}$ & $-1.122-0.363 x_{1}-0.407 x_{2}$ & Max \\
\hline \multirow[t]{3}{*}{$\mathrm{BF}$} & $\mathrm{NPN}-\mathrm{N}\left(\% \mathrm{w} / \mathrm{w}_{\mathrm{TN}}\right)$ & $x_{1}$ & $0.777+0.240 x_{2}+0.169 x_{3}$ & $\operatorname{Max}$ \\
\hline & & $x_{2}$ & $-1.102-0.057 x_{1}-0.053 x_{3}$ & Min \\
\hline & & $x_{3}$ & $-0.591+0.204 x_{1}+0.267 x_{2}$ & $\operatorname{Max}$ \\
\hline \multirow[t]{3}{*}{$\mathrm{BF}$} & PTA-N $\left(\% \mathrm{w} / \mathrm{w}_{\mathrm{TN}}\right)$ & $x_{1}$ & $0.230+0.037 x_{2}+0.055 x_{3}$ & Max \\
\hline & & $x_{2}$ & $-1.153-0.014 x_{1}+0.040 x_{3}$ & Min \\
\hline & & $x_{3}$ & $1.291-0.187 x_{1}+0.358 x_{2}$ & Min \\
\hline \multirow[t]{3}{*}{$\mathrm{BF}$} & Fat acidity $\left(\mathrm{mg}_{\mathrm{KOH}} / \mathrm{g}_{\mathrm{fat}}\right)$ & $x_{1}$ & $0.423+0.284 x_{2}-0.229 x_{3}$ & $\operatorname{Max}$ \\
\hline & & $x_{2}$ & $-1.147-0.267 x_{1}+0.268 x_{3}$ & Min \\
\hline & & $x_{3}$ & $-1.818-0.828 x_{1}-1.028 x_{2}$ & Max \\
\hline \multirow[t]{3}{*}{$\mathrm{TF}$} & Hardness $(\mathrm{N})$ & $x_{1}$ & $0.317-0.142 x_{2}+0.106 x_{3}$ & Min \\
\hline & & $x_{2}$ & $0.042+0.051 x_{1}+0.048 x_{3}$ & $\operatorname{Max}$ \\
\hline & & $x_{3}$ & $-0.152-0.163 x_{1}+0.208 x_{2}$ & Max \\
\hline
\end{tabular}

viable numbers of Enterobacteriaceae, the milk composition is obviously comprised between -1 and +1 ; the restriction $x_{1}=+1$ (which is the uppermost fraction of caprine milk in the cheese milk blend) will lead to the longest ripening time ever (see Table 11). For the other parameters in question, the restriction $x_{2}=0$ or $x_{2}=+1$ (i.e., ripening for 120 days, the minimum value allowed by the AOP regulation, or for 195 days, respectively) was imposed since the longer the ripening period the more intense the proteolysis and lipolysis phenomena in cheese, and the safer the cheese in microbiological terms.

Inspection of Table 11 indicates that there is not a single optimum for all the microbiological and biochemical factors considered simultaneously. However, since minimisation of viable numbers of Enterobacteriaceae and staphylococci is probably the most important

Table 11

Global optima, in terms of caprine milk fraction in cheesemilk $(L)$, ripening time $(t)$ and amount of salt added to fresh cheese $(s)$

\begin{tabular}{|c|c|c|c|c|c|}
\hline Factor & Restriction imposed & $L(\% \mathrm{v} / \mathrm{v})$ & $t$ (days) & $s(\% \mathrm{w} / \mathrm{w})$ & Optimum value \\
\hline Microbiological & Minima & & & & \\
\hline \multirow{3}{*}{ Enterobacteriaceae (c.f.u./g $g_{\text {cheese }}$ ) } & $x_{1}=-1$ & 20.0 & 107 & 16.2 & $<0$ \\
\hline & $x_{1}=0$ & 50.0 & 179 & 14.1 & $4.08 \times 10^{3}$ \\
\hline & $x_{1}=+1$ & 80.0 & 88 & 12.2 & $7.77 \times 10^{3}$ \\
\hline Staphylococci (c.f.u./gcheese $)$ & - & 49.1 & 92 & 14.9 & $1.88 \times 10^{6}$ \\
\hline Biochemical & Maxima & & & & \\
\hline \multirow[t]{2}{*}{$\mathrm{WSN}\left(\% \mathrm{w} / \mathrm{w}_{\mathrm{TN}}\right)$} & $x_{2}=0$ & 80.7 & 120 & 10.5 & 20.9 \\
\hline & $x_{2}=+1$ & 88.0 & 195 & 9.0 & 33.0 \\
\hline \multirow[t]{2}{*}{$\mathrm{NPN}-\mathrm{N}\left(\% \mathrm{w} / \mathrm{w}_{\mathrm{TN}}\right)$} & $x_{2}=0$ & 71.0 & 120 & 13.7 & 15.1 \\
\hline & $x_{2}=+1$ & 79.9 & 195 & 14.6 & 26.8 \\
\hline \multirow[t]{2}{*}{ Fat acidity $\left(\mathrm{mg}_{\mathrm{KOH}} / \mathrm{g}_{\mathrm{fat}}\right)$} & $x_{2}=0$ & 54.9 & 120 & 16.4 & 16.8 \\
\hline & $x_{2}=+1$ & 58.1 & 195 & 18.1 & 33.3 \\
\hline
\end{tabular}


issue owing to legal hygiene standards currently enforced by the EU, our results indicate opposite tendencies in what concerns milk type effect and salt effect, i.e., higher contents of caprine milk and lower contents of $\mathrm{NaCl}$ lead to higher viable numbers of Enterobacteriaceae. However, if one looked at the ripening effect, and bearing in mind that the minimum ripening period of Picante cheese is 120 days, then $50 \%(\mathrm{v} / \mathrm{v})$ caprine milk and ca. $14 \%(\mathrm{w} /$ $\mathrm{w}_{\mathrm{TS}}$ ) $\mathrm{NaCl}$ would become acceptable optimum values for cheesemilk composition and salt content, respectively. It cannot be forgotten that the microbiological quality of raw milk is unfortunately quite variable, especially in what concerns small ruminants' milks. Coupling this concern of microbiological quality with the degrees of proteolysis and lipolysis of typical Picante cheese, which increase significantly between 110 and 180 days of ripening irrespective of the fractional composition of caprine milk (Freitas et al., 1997), 6 months of ripening seems adequate for this type of cheese.

In terms of biochemical parameters, it seems that their maximisation is possible between ca. $60 \%(\mathrm{v} / \mathrm{v})$ for fat acidity and ca. $80 \%(\mathrm{v} / \mathrm{v})$ caprine milk for WSN and NPN-N, coupled with 195 days of ripening and $\mathrm{NaCl}$ content in the range $9-18 \%\left(\mathrm{w} / \mathrm{w}_{\mathrm{TS}}\right)$. According to data reported by Freitas et al. (1997), milk composition is a significant factor with respect to the concentration of nitrogen fractions: cheese manufactured with $50 \%, 75 \%$ and $100 \%(\mathrm{v} / \mathrm{v})$ caprine milk exhibited higher values of WSN and NPN by 180 days of ripening than cheese manufactured with $0 \%$ and $25 \%(\mathrm{v} / \mathrm{v})$ caprine milk by the same time. Although the effect of composition of the cheesemilk blend was not statistically significant in terms of the organoleptic parameters analysed, the cheese manufactured with $75 \%$ and $100 \%$ (v/v) caprine milk received the highest scores in terms of texture and flavour (Freitas et al., 1997).

Due to lack of consensus in terms of optima for the three effects, Table 12 lists estimated values for the parameters when subjected to the constraints posed by Eq. $1, x_{1}=0$ and $x_{1}=+1$ (i.e., $50 \%$ and $80 \%(\mathrm{v} / \mathrm{v})$ caprine milk), $x_{2}=+1$ (i.e., 195 days of ripening) and $x_{3}=0$ (i.e., $\left.15 \%\left(\mathrm{w} / \mathrm{w}_{\mathrm{TS}}\right) \mathrm{NaCl}\right)$, as well as values measured in Picante cheese manufactured with $50 \%$ and $75 \%(\mathrm{v} / \mathrm{v})$ caprine milk, ripened for 180 days and possessing 19.8\% or $18.8 \%\left(\mathrm{w} / \mathrm{w}_{\mathrm{TS}}\right) \mathrm{NaCl}$, respectively. It is interesting to observe that some of the estimated values are close to those obtained in previous work (Freitas et al., 1995, 1997); this is particularly the case of the negligible viable numbers of Enterobacteriaceae and yeasts (as viable numbers of enterococci and LAB could not be compared because enumeration of these groups was performed on different selective media). In terms of

Table 12

Estimated values for the microbiological, physicochemical, biochemical and textural parameters obtained when technological factors are set at their optimum levels (i.e., $50 \%$ and $80 \%$ caprine milk, 195 days and $15 \%\left(\mathrm{w} / \mathrm{w}_{\mathrm{TS}}\right) \mathrm{NaCl}$ ) and experimental values obtained from Picante cheese manufactured with $50 \%$ and $75 \%$ (v/v) caprine milk, ripened for 180 days and containing $19.8 \%$ and $18.8 \%\left(\mathrm{w} / \mathrm{w}_{\mathrm{TS}}\right) \mathrm{NaCl}(\mathrm{Freitas}$ et al., 1995, 1997)

\begin{tabular}{|c|c|c|c|c|}
\hline \multirow[t]{2}{*}{ Factor } & \multicolumn{2}{|l|}{ Estimated values } & \multicolumn{2}{|l|}{ Picante cheese } \\
\hline & $\begin{array}{l}L=50 \%(\mathrm{v} / \mathrm{v}), \\
t=195 \text { days, } \\
s=15 \%\left(\mathrm{w} / \mathrm{w}_{\mathrm{TS}}\right)\end{array}$ & $\begin{array}{l}L=80 \%(\mathrm{v} / \mathrm{v}), \\
t=195 \text { days, } \\
s=15 \%\left(\mathrm{w} / \mathrm{w}_{\mathrm{TS}}\right)\end{array}$ & $\begin{array}{l}L=50 \%(\mathrm{v} / \mathrm{v}) \\
t=180 \text { days, } \\
s=19.8 \%\left(\mathrm{w} / \mathrm{w}_{\mathrm{TS}}\right)\end{array}$ & $\begin{array}{l}L=75 \%(\mathrm{v} / \mathrm{v}) \\
t=180 \text { days } \\
s=18.8 \%\left(\mathrm{w} / \mathrm{w}_{\mathrm{TS}}\right)\end{array}$ \\
\hline \multicolumn{5}{|c|}{ Microbiological (c.f.u./g $/ \mathrm{g}_{\text {cheese }}$ ) } \\
\hline Enterobacteriaceae & $1.42 \times 10^{2}$ & $<0$ & $\mathrm{ND}^{\mathrm{a}}$ & ND \\
\hline Staphylococci & $<0$ & $<0$ & ND & $4.38 \times 10^{3} \pm 1.11 \times 10^{3}$ \\
\hline Enterococci & $2.42 \times 10^{3}$ & $3.55 \times 10^{3}$ & $\mathrm{NC}^{\mathrm{b}}$ & $\mathrm{NC}$ \\
\hline LAB & $9.68 \times 10^{2}$ & $2.76 \times 10^{3}$ & $\mathrm{NC}$ & $\mathrm{NC}$ \\
\hline yeasts & $<0$ & $<0$ & ND & ND \\
\hline \multicolumn{5}{|l|}{ Physicochemical } \\
\hline Outer $\mathrm{pH}$ & 5.50 & 5.57 & $6.27 \pm 0.03$ & $6.32 \pm 0.03$ \\
\hline Inner $\mathrm{pH}$ & 5.45 & 5.49 & $5.89 \pm 0.03$ & $5.80 \pm 0.06$ \\
\hline Moisture $(\% \mathrm{w} / \mathrm{w})$ & 41.63 & 41.50 & $40.28 \pm 0.41$ & $38.84 \pm 0.08$ \\
\hline Total protein $(\% \mathrm{w} / \mathrm{w})$ & 19.18 & 18.98 & $18.21 \pm 0.72$ & $18.30 \pm 0.78$ \\
\hline Total fat $(\% \mathrm{w} / \mathrm{w})$ & 30.78 & 29.87 & 30.25 & 32.75 \\
\hline \multicolumn{5}{|l|}{ Biochemical } \\
\hline $\mathrm{WSN}\left(\% \mathrm{w} / \mathrm{w}_{\mathrm{TN}}\right)$ & 31.87 & 32.45 & $27.19 \pm 0.16$ & $27.06 \pm 0.37$ \\
\hline NPN-N $\left(\% \mathrm{w} / \mathrm{w}_{\mathrm{TN}}\right)$ & 25.86 & 26.75 & $23.42 \pm 0.14$ & $24.96 \pm 0.13$ \\
\hline Fat acidity $\left(\mathrm{mg}_{\mathrm{KOH}} / \mathrm{g}_{\mathrm{fat}}\right)$ & 30.68 & 28.05 & 20.83 & 19.73 \\
\hline \multicolumn{5}{|l|}{ Textural } \\
\hline Hardness $(\mathrm{N})$ & 4.22 & 5.39 & $\mathrm{NA}^{\mathrm{c}}$ & NA \\
\hline
\end{tabular}

\footnotetext{
${ }^{a} \mathrm{ND}$ - Not detected.

${ }^{\mathrm{b}} \mathrm{NC}$ - Not comparable owing to enumeration on different selective media.

${ }^{\mathrm{c}} \mathrm{NA}$ - Not available.
} 
staphylococci, the optima found were characterised by lower viable numbers, especially regarding cheese manufactured with $75 \%$ (v/v) caprine milk. Discrepancies are nonetheless observed in terms of $\mathrm{pH}$ values, for which the optima were characterised by lower values than those for the traditional cheese; however, moisture and total protein and fat contents are very close to one another. Values relatively similar to those of the traditional cheese were estimated by the global optima for WSN and NPN, but not for fat acidity (which was much higher).

According to Anon (1988), Picante cheese is a semihard or hard ripened cheese that can be sold after 120 days of ripening; the only legal specification for composition of this cheese is moisture content ranging between $49 \%$ and $63 \%$ in fat free basis and fat content ranging between $35 \%$ and $60 \%$ in dry basis. Both data generated in previous work and in the present study are in accordance with said legal specifications, as can be observed from inspection of Table 12.

\section{Conclusions}

Although optimisation of Picante cheese manufacture should in principle result from a compromise between several objective functions encompassing sensory, microbiological, physicochemical and biochemical characteristics, objective functions directly related to the safety of the product (i.e., reduction of viability of undesirable bacteria such as Enterobacteriaceae and staplylococci) and biochemical characteristics (i.e., increase of extents of proteolysis and lipolysis) permit determination of a consistent and reasonable set of optimum technological conditions: (1) the range 50$80 \%(\mathrm{v} / \mathrm{v})$ caprine milk in cheesemilk seems adequate because the differences in terms of microbiological safety, proteolysis and lipolysis extents are not very high; (2) 195 days is the best period for ripening, which confirms once more that this type of cheese should be ripened for no less than 120 days; and (3) $15 \%$ (w/w $\mathrm{w}_{\mathrm{TS}}$ ) $\mathrm{NaCl}$ should be employed, which means salting fresh Picante cheese (ca. 66\% (w/w) moisture) with ca. 5\% (w/w) $\mathrm{NaCl}$.

\section{Acknowledgements}

The authors are grateful to the members of the technical board of the Governmental Directorate of Agriculture for the Region of Beira Interior (DRABI, Portugal) for their cooperation in supervising milk collection and for transporting such milk to the ESB premises for analysis. Financial support for author Cristina Freitas was provided by Ph.D. fellowships, BD/
2111/92-IF and BD/5364/95-IF, under the auspices of programs CIENCIA and PRAXIS XXI, respectively (JNICT and FCT, Portugal). Partial financial support for the research program was provided by project PROTOLACTIS: PROdução, por Tecnologias Optimizadas, de LACticínios TradicionaIS, administered by PAMAF (INIA, Portugal) and coordinated by author Xavier Malcata.

\section{References}

Albrecht, T. W., \& Jaynes, H. O. (1955). Milk lipases. J. Dairy Sci., 38, 137.

Anon, (1975). Fromages. Détermination de la teneur en matière grasse. Butyromètre pour la méthode van Gulik. Norme Internationale ISO no. 3432. Nederlands Normalisetie Institut, Delft, The Netherlands.

Anon (1988). Diário da Républica. I-Série, No 121 de 25-5-1988. Decreto Lei Regulamentar No 22/88. Imprensa Nacional, Casa da Moeda, Lisbon, Portugal.

Box, G. E. P., Hunter, W. G., \& Hunter, J. S. (1978). Statistics for experimenters - An introduction to design, data analysis and model building (pp. 510-535). New York: Wiley.

Bucheim, V. W., Lund, S., Scholtissek, J. (1989). Comparative studies on the structure and size of casein micelles in milk from different species. Kiel. Milchwirtsch. Forsch., 41, 253.

Chen, A. H., Larkin, J. W., Clark, C. J., \& Irwin, W. E. (1979). Textural analysis of cheese. J. Dairy Sci., 62, 901.

Farkye, N. Y., Fox, P. F. (1990). Objective indices of cheese ripening. Trends Food Sci. Technol., 1, 37-40.

Freitas, A. C., \& Malcata, F. X. (1998). Lipolysis in Picante cheese: Influence of milk type and ripening time on free fatty acid profile. Lait, 78, 251-258.

Freitas, A. C., \& Malcata, F. X. (1996). Influence of milk type, coagulant, salting procedure and ripening time on the final characteristics of Picante cheese. Int. Dairy J., 6, 1099-1116.

Freitas, A. C., Fresno, J. B., Prieto, B., Malcata, F. X., \& Carballo, F. J. (1997). Effects of ripening time and combination of ovine and caprine milks on proteolysis of Picante cheese. Food Chem., 2, 219229.

Freitas, A. C., Pais, C., Malcata, F. X., \& Hogg, T. A. (1996). Microbiological characterization of Picante da Beira Baixa cheese. J. Food Prot., 59, 155-160.

Freitas, A. C., Pintado, A. E., Pintado, M. E., \& Malcata, F. X. (1999). Role of dominant microflora of Picante cheese on proteolysis and lipolysis. Int. Dairy J. (in press).

Freitas, A. C., Sousa, M., \& Malcata, F. X. (1995). Effect of ripening time and the combination of ewe and goat milk on the microflora of Picante cheese. Ital. J. Food Sci., 7, 361-377.

Furtado, M. M., Partridge, J. A. (1998). Characterization of nitrogen fractions during ripening of a soft cheese made from ultrafiltration retentates. J. Dairy Sci., 71, 2877-2884.

Geurts, T. J., Walstra, P., \& Mulder, P. (1974a). Neth. Milk Dairy J., $28,46$.

Geurts, T. J., Walstra, P., \& Mulder, P. (1974b). Neth. Milk Dairy J., 28,102 .

Geurts, T. J., Walstra, P., \& Mulder, P. (1980). Neth. Milk Dairy J., 34, 229

Gomes, A. M. P., \& Malcata, F. X. (1998). Development of probiotic cheese manufactured from goat milk: response surface analysis via technological manipulation. J. Dairy Sci., 81, 1492-1507.

Guinee, T. P., \& Fox, P. F. (1993). Salt in cheese: physical, chemical and biological aspects. In: P. F. Fox, Cheese: chemistry, physics and microbiology (pp. 257-302). London: Chapman \& Hall. 
Guinee, T. P., \& Wilkinson, M. G. (1992). Rennet coagulation and coagulants in cheese manufacture. J. Soc. Dairy Technol., 45, 94 104.

Holt, J. G., Krieg, N. R., Sneath, P. H. A., Staley, J. T., Williams, S.T. (Ed.) (1989). Bergey's manual of determinative bacteriology. Baltimore, MA, USA: Williams \& Wilkins.

Kleter, G. (1977). The ripening of Gouda cheese made under strictly aseptic conditions. II. The comparisons of the activity of different starters and the influence of certain lactobacilli strains. Neth. Milk Dairy J., 31, 177-187.

Kosikowski, F. V. (1982). Cheese and fermented milk foods. New York NY, USA: Edwards Brothers.

Lawrence, R. C., Heap, H. A., \& Gilles, J. (1984). A controlled approach to cheese technology. J. Dairy Sci., 67, 1632-1645.

Macedo, A. C., \& Malcata, F. X. (1998b). Technological optimization of the manufacture of Serra cheese. J. Food Eng., 31, 433-447.

Malcata, A. M. C. M. (1996). Microbiological, chemical, biochemical and technological contributions to the characterisation and improvement of Serra da Estrela cheese. Ph.D. dissertation, Escola Superior de Biotecnologia, Universidade Católica Portuguesa, Porto.

Mallatou, H., Pappas, C. P., \& Voutsinas, L. P. (1994). Manufacture of Feta cheese from sheep's milk, goat's milk or mixtures of these milks. Int. Dairy J., 4, 641-664.

Marshall, B. Y., Ohye, D. B., \& Christian, J. H. B. (1971). Tolerance of bacteria to high concentration of $\mathrm{NaCl}$ and glycerol on the growth medium. J. Appl. Microbiol., 21, 363-364.

Measures, J. C. (1975). Role of amino acids in osmoregulation of nonhalophilic bacteria. Nature, 257, 398-400.

Nabais, R. M., \& Malcata, F. X. (1995). Optimizing a lactic fermentation of sliced carrots. J. Food Proc. Preserv., 19, 427.
Pintado, M. E., Lopes da Silva, J. A., \& Malcata, F. X. (1996). Characterization of Requeijão and technological optimization of its manufacturing process. J. Food Eng., 30, 363-376.

Richardson, G. E. (Ed.) (1985). Standard methods for the examination of dairy products. Washington DC, USA: American Public Health Association.

Richardson, B. C., Creamer, L. K., Pearce, K. N. (1974). Comparative micelle structure. II. Structure and composition of casein micelles in ovine and caprine milks as compared with those in bovine milk. J. Dairy Res., 41, 239.

Schroeder, C. L., Bodyfelt, F. W., Wyatt, C. J., \& McDaniel, M. R. (1988). Reduction of sodium chloride in Cheddar cheese: effect on sensory, microbiological, and chemical properties. J. Dairy Sci., 71, 2010-2020.

Visser, S. (1993). Proteolytic enzymes and their relation to cheese ripening and flavour: an overview. J. Dairy Sci., 76, 329.

Visser, F. M. W. (1977a). Contribution of enzymes from rennet, starter bacteria and milk to proteolysis and flavour development in Gouda cheese. 2. Development of bitterness and cheese flavour. Neth. Milk Dairy J., 31, 188-209.

Visser, F. M. W. (1977b). Contribution of enzymes from rennet, starter bacteria and milk to proteolysis and flavour development in Gouda cheese. 3. Protein breakdown: analysis of the soluble nitrogen and amino acid nitrogen fraction. Neth. Milk Dairy J., 31, 210-239.

Wilkinson, M. G., Guinee, T. P., O'Callaghan, D. M., \& Fox, P. F. (1992). Effects of commercial enzymes on proteolysis and ripening in Cheddar cheese. Lait, 72, 449-459.

Woo, A. H., Kollodge, S., Lindsay, R. C. (1984). Quantification of major free fatty acids in several cheese varieties. J. Dairy Sci., 67, 874-878. 